\title{
Supplementation of crossbred cows with maize and urea in tropical pasture
}

[Suplementação de vacas mestiças com milho e ureia em pastagem tropical]

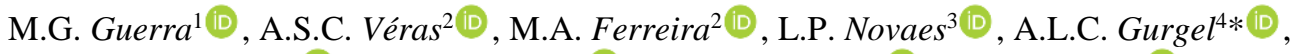

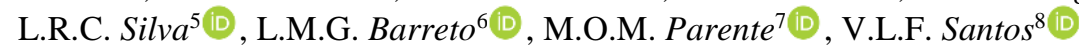 \\ ${ }^{1}$ Graduate, Universidade Federal Rural de Pernambuco, Recife, PE, Brasil \\ ${ }^{2}$ Universidade Federal Rural de Pernambuco, Recife, PE, Brasil \\ ${ }^{3}$ Universidade Federal do Rio Grande do Norte, Macaíba, RN, Brasil \\ ${ }^{4}$ Graduate, Universidade Federal do Mato Grosso do Sul, Campo Grande, MS, Brasil \\ ${ }^{5}$ Graduate, Universidade Rural Federal do Semiárido, Mossoró, RN, Brasil \\ ${ }^{6}$ Universidade Federal de Sergipe, Nossa Senhora da Glória, SE, Brasil \\ ${ }^{7}$ Universidade Federal do Maranhão, Chapadinha, MA, Brasil \\ ${ }^{8}$ Universidade Federal do Piauí, Bom Jesus, PI, Brasil
}

\begin{abstract}
This research article aims to evaluate the effect of total replacement of corn by soybean meal and urea on intake and apparent digestibility of dry matter and its components, production and composition of milk and feeding behavior of lactating cows grazing, with intermittent stocking Mombaça grass (Megathyrsus maximus cv. Mombaça). Twelve milking cows were distributed in a triple 4 x 4 latin square. Experimental treatments consisted of four soybean meal replacement levels by corn more urea $(0 ; 33 ; 66 ; 100 \%)$. The grass has an average content of crude protein and neutral detergent fiber of $19 \%$ and $59 \%$, respectively. The replacement of soybean meal by corn and urea did not affect the intake and digestibility of nutrients. A linear reduction of milk production was observed, but there was no change in milk production corrected to $4.0 \%$ of fat. The milk components $(\mathrm{g} / \mathrm{kg})$ of fat, protein, lactose, and total solids were not altered, as well as feeding behavior. Under the conditions of this study, the replacement of the diets is suitable for crossbred dairy cows in lactation third medium, producing in average of $12.5 \mathrm{~kg} / \mathrm{day}^{-1}$ when kept in quality pastures.
\end{abstract}

Keywords: grazing, intake, milk composition, milk production, protein

\section{RESUMO}

Este artigo de pesquisa tem como objetivo avaliar o efeito da substituição total do milho pelo farelo de soja e ureia sobre o consumo e a digestibilidade aparente da matéria seca e de seus componentes, a produção e a composição do leite e o comportamento alimentar de vacas em lactação mantidas em pastos capim-mombaça (Megathyrsus maximus cv. Mombaça) manejado sob lotação intermitente. Doze vacas em lactação foram distribuídas em um quadrado latino triplo $4 \times 4$. Os tratamentos experimentais consistiram de quatro níveis de substituição do farelo de soja pelo milho mais ureia $(0 ; 33 ; 66 ; 100 \%)$. O capimmombaça apresentou um teor médio de proteína bruta e de fibra em detergente neutro de 19\% e 59\%, respectivamente. A substituição do farelo de soja por milho e ureia não afetou o consumo e a digestibilidade dos nutrientes. Observou-se redução linear da produção de leite, mas não houve alteração na produção de leite corrigida para 4,0\% de gordura. Os componentes do leite ( $\mathrm{g} / \mathrm{kg})$ : gordura, proteína, lactose e sólidos totais não foram alterados, assim como o comportamento ingestivo dos animais. Nas condições deste estudo, a substituição total do milho pelo farelo de soja e ureia nas dietas é adequada para vacas mestiças leiteiras em terço médio de lactação, produzindo, em média, $12,5 \mathrm{~kg} / \mathrm{dia}^{-1}$ quando mantidas em pastagens de qualidade.

Palavras-chave: composição do leite, ingestão, pastejo, produção de leite, proteína

*Corresponding author: antonioleandro09@gmail.com

Submitted: April 29, 2021. Accepted: June 11, 2021. 


\section{INTRODUCTION}

The Brazilian cattle industry is characterized by the production of most of its animals under pasture condition (Gurgel et al., 2020a). Tropical pasture when fertilized and rightly irrigated, has the capacity to produce more dry matter (DM) with better nutritional quality, promoting better animal productivity and profitability of activity.

Tropical grasses such as Megathyrsus maximus, have been used especially as forage for their high nutritional value, forage production and support capabilities, and high acceptability by the animals and the absence of anti-nutritional factors (Difante et al., 2010; Euclides et al., 2018; Emerenciano Neto et al., 2020).

The soybean meal is a major source of dietary protein used for all species of production. For ruminants, the inclusion of this ingredient can result in higher dietary cost. Therefore, the use of other protein sources instead of soybean meal may be a strategy to reduce production costs of dairy farming, not compromising its performance (Naves et al., 2015; Pontes et al., 2020).

Urea is an ingredient widely used as non-protein nitrogen source (NPN) in the ruminants' diet. In addition to its low cost in the market, the great advantage of this product is the ability rumen microorganisms have to turn the NPN into microbial protein (Gonçalves et al., 2014; Ítavo et al., 2016). Protein replacement grain arising by NPN has been proposed as a way to reduce the competition between human and animal protein for food (Moraes et al., 2019).

Thus, it was assumed that replacement of soybean meal with corn and urea in diets of lactating crossbred cows, maintained in irrigated pastures of mombaça grass and fertilized, does not alter the consumption and digestibility of dry matter and its components, milk production and composition and feeding behavior. Therefore, the aim of this study was to evaluate the effect of replacing soybean meal by corn and urea in diets for dairy cows intermittent grazing of Mombasa, on the intake and digestibility of dry matter and its components, production and milk composition and feeding behavior.

\section{MATERIALS AND METHODS}

All procedures performed in studies involving animals were in accordance with the ethical standards of the institution or practice where the studies were conducted. Ethics Committee on Animal Use - CEUA - Federal University of Rio Grande do Norte - UFRN, through the 065/2014 protocol number.

The experiment was conducted in the Dairy Cattle Department of the UFRN (Federal University of Rio Grande do Norte), in the city of Macaíba, RN, Brazil. 12 crossbred cows (with blood degree, predominantly, of the Holstein breed) were used, with body weight (BW) initial average of $473.0 \pm 45.0 \mathrm{~kg}$, average days lactation $95.0 \pm 42.2$ and average initial milk production $14.1 \pm 1, \overline{9} \mathrm{~kg} \mathrm{a}$ day. The experimental design was $4 \times 4$ Latin square, triple, considering grouping criteria, milk production (MP) and the physiological condition.

The treatments consisted in the substitution of soybean meal for corn and urea $(0 ; 33 ; 66 ; 100 \%)$. The diet with no urea has been formulated according to NRC (Nutrient..., 2001), to meet the requirements of cows' $473 \mathrm{~kg} \mathrm{BW}$ and average daily production of $14.0 \mathrm{~kg}$ of milk with $4.0 \%$ fat (Table 1).

The experiment lasted for 68 days, divided into four periods of 17 days, of which 10 were for adaptation of animals to the diets and the next seven days for data collection and samples. The animals were fed by concentrated supplementation individually during the morning milking (6am) and afternoon (2pm), which was provided $1 \mathrm{~kg}$ of concentrate (based on dry matter - DM) for every $2 \mathrm{~kg}$ of milk produced above $8 \mathrm{~kg}$.

The animals were kept in an area of mombaça grass of 1.65 ha, divided into 17 paddocks of $900 \mathrm{~m}^{2}$. The grazing method was intermittent stocking, with one day of occupation and 16 days of rest. The experimental area soil was classified as a Quartzarenic Neosol (Teixeira et al., 2018), immediately after the animals left, the paddocks were fertilized with $400 \mathrm{~kg}$ / ha of $\mathrm{NPK}\left(\mathrm{N}, \mathrm{P}_{2} \mathrm{O}_{5}\right.$, $\mathrm{K}_{2} \mathrm{O}$ ). Irrigation was held from $7 \mathrm{am}$ to $4 \mathrm{pm}$, every other day. The soil analysis, fertilization and irrigation were carried out according to the management adopted in the cattle sector of the UFRN. 
Supplementation of crossbred...

Table 1. Percentage composition and chemical concentrates, due to replacement levels

\begin{tabular}{|c|c|c|c|c|c|}
\hline \multirow{2}{*}{ Ingredients } & \multirow{2}{*}{ Mombasa grass } & \multicolumn{4}{|c|}{ Replacement levels (\%) } \\
\hline & & 0 & 33 & 66 & 100 \\
\hline Ground corn & - & 62.0 & 67.5 & 72.9 & 78.4 \\
\hline Soybean meal & - & 19.4 & 12.9 & 6.5 & 0.0 \\
\hline Wheat meal & - & 14.3 & 14.3 & 14.3 & 14.3 \\
\hline Urea/ammonium sulfate $^{1}$ & - & 0.0 & 1.0 & 2.0 & 3.0 \\
\hline Mineral mix & - & 4.3 & 4.3 & 4.3 & 4.3 \\
\hline \multicolumn{6}{|c|}{ Chemical composition (g/kg DM) } \\
\hline Dry matter* & 200.7 & 860.3 & 850.9 & 841.4 & 832.0 \\
\hline Organic matter ${ }^{2}$ & 904.1 & 927.8 & 920.8 & 913.8 & 906.8 \\
\hline Crude protein ${ }^{2}$ & 190.7 & 173.2 & 173.4 & 174.1 & 174.3 \\
\hline Ether extract ${ }^{2}$ & 24.0 & 32.9 & 34.0 & 35.1 & 36.2 \\
\hline Neutral detergent fiber ${ }^{2}$ & 595.0 & 164.6 & 163.2 & 161.9 & 160.5 \\
\hline Acid detergent fiber ${ }^{2}$ & 303.1 & 48.6 & 41.7 & 34.9 & 28.0 \\
\hline Total carbohydrates ${ }^{2}$ & 677.0 & 726.5 & 740.4 & 753.9 & 767.8 \\
\hline Non-fiber carbohydrates ${ }^{2}$ & 94.3 & 456.5 & 469.8 & 482.8 & 496.1 \\
\hline $\mathrm{NDICP}^{3}$ & 9.9 & 3.4 & 1.4 & 3.1 & 2.9 \\
\hline $\mathrm{ADICP}^{4}$ & 1.0 & 0.2 & 0.2 & 0.1 & 0.1 \\
\hline
\end{tabular}

${ }^{*} \mathrm{~g} / \mathrm{kg}$ of natural matter; ${ }^{1}$ Nine parts of urea to one part of ammonium sulfate mixed in the concentrate of diet was used; ${ }^{2} \mathrm{~g} / \mathrm{kg}$ of DM; ${ }^{3}$ Neutral detergent insoluble crude protein; ${ }^{4}$ Acid detergent insoluble crude protein.

In order to evaluate the quality of the fiber material ingested by the animal, the simulated pasture was manually performed on the first and last days of each collection period to obtain composite samples for paddock and period.

The consumption of forage was estimated using the external label Titanium Dioxide (TD). In each period, for 12 consecutive days, all animals received orally 15 grams of $\mathrm{TD}$, divided into two daily supplies and administered by gavage. In the last five days of supply of the label, individual samples of feces from the rectum of animals were collected twice daily. Stool samples were frozen at $-20^{\circ} \mathrm{C}$ and after the end of the collection period; the samples from each animal were thawed and combined to form a single sample per animal. Then the samples were dried at $55-60{ }^{\circ} \mathrm{C}$ for $120 \mathrm{~h}$ and ground in a $2 \mathrm{~mm}$ colander. The analysis of the fecal concentration of TD was performed as Detmann et al. (2012).

The content of DM, mineral matter (MM), crude protein $(\mathrm{CP})$, ether extract $(\mathrm{EE})$, neutral detergent fiber (NDF) and acid detergent fiber (FDA), nitrogen $(\mathrm{N})$ neutral detergent insoluble (NDIN) and acid detergent (NIDA) in samples of grass, the concentrated ingredients and feces were obtained according Detmann et al. (2012).

The indigestible neutral detergent fiber (iNDF) was used as internal label to estimate fecal excretion of dry matter. Fecal samples and food were pre-dried at $55-60^{\circ} \mathrm{C}$, ground to a sieve of 2 $\mathrm{mm}$ and evaluated for NDFi content using nonwoven fabric bags (TNT $100 \mathrm{~g} / \mathrm{m}^{2}$ ), incubated in situ for a period of $288 \mathrm{~h}$, according to Valente $e t$ al. (2011). To this end, an adult bovine was used with PC $600 \mathrm{~kg}$, fed a diet consisting of $80 \%$ of elephant grass silage and $20 \%$ concentrate, after ten days of adaptation.

The animals were mechanically milked twice a day and milk production (MP) was measured daily. MP corrected for $4 \%$ fat (MPCF) was obtained according to NRC (Nutrient..., 2001). In the first and second days of each collection period was sampled milk produced in the milking proportion $(2 \%$ by volume produced in the respective shift day) per animal. Milk samples were stored in containers for later protein analysis, fat, lactose, total solids, casein and ureic nitrogen, with Bentley 2000 equipment by infrared absorption.

On the last day of each experimental period, blood samples were collected from each animal through the jugular vein for analysis of non-esterified fatty acids (NEFA). The analysis was made by Johnson and Peters (1993) method using the analytical commercial kit Randox ${ }^{\circledR}$ NEFA spectrophotometrically at $550 \mathrm{~nm}$ on ELISA plate reader 96 cavities. 
The breaks activities (BA), ruminating (RUM) and feeding (FED) were recorded by visual observation by instant scanning method, in tenminute break, adapted for 24 hours, starting out at $7 \mathrm{am}$ and ended at 7 am the next morning.

Feed times (FT min/day), rumination (RT, min / day), entertainment (ST, min/day) and chewing (TCT $\mathrm{min} /$ day) and rumination efficiencies depending on the dry matter (REDM/min) and neutral detergent fiber (RENDF/min) and the dry matter feed efficiency (PEDM/ min) and neutral detergent fiber (FENDF/min) were evaluated according to Bürger et al. (2000).

Data were subjected to analysis of variance and the effect of the treatments was checked by regression analysis, using the MIXED statistical software by SAS, version 9.1. The following statistical model was used:

$$
\text { Yijkl }=\mu+\mathrm{Ti}+\mathrm{Pj}+\mathrm{Ak}+\mathrm{Ls}+\alpha \mathrm{ijkl}
$$

where yijkl = value observed in period $\mathrm{j}$, animal $\mathrm{k}$ and Latin square $s$, for treatment $\mathrm{j} ; \mu=$ overall mean; $\mathrm{Ti}=$ effect of treatment $\mathrm{i}(0,33,66$ and $100 \%$ replacement); $\mathrm{Pj}=$ effect of period $\mathrm{j}$ ( 1 to 4); Ak = effect of animal k (1 to 12); Ls = effect of Latin squares $(1 ; 2$ and $) ; \alpha i j k l=$ random-error component associated with treatment $\mathrm{i}$, period $\mathrm{j}$, animal $\mathrm{k}$ and Latin squares. The significance level was set at $5 \%$ for all statistical analyses.

\section{RESULTS}

The chemical composition of samples originated from the simulated grazing Mombasa grass was $200.7 \mathrm{~g} \mathrm{DM} / \mathrm{kg}$ of fresh matter (FM); 904.1g of organic matter (OM); $190.7 \mathrm{~g}$ of $\mathrm{PB} ; 595.0 \mathrm{~g}$ of $\mathrm{NDF}$ and $94.3 \mathrm{~g}$ of non-fibrous carbohydrates (NFC).

There was no influence of corn and urea levels on consumption and apparent digestibility of pasture, total DM, organic matter (OM), CP, NDF. However, intake of NFC showed linear increase $(\mathrm{P}<0.05)$ as shown in Table 2.

PL decreased linearly with replacement levels, there was a reduction of $0.0087 \mathrm{~kg} /$ day for each replacement levels. The milk components and milk urea nitrogen (MUN) have not changed (Table 3).

The non-esterified fatty acids (NEFA) were not affected when soybean meal was replaced by corn and urea, as well as feeding behavior of animals. (Table 4).

Table 2. Intake and digestibility of nutrients, according to the substitution levels

\begin{tabular}{|c|c|c|c|c|c|c|c|}
\hline \multirow{2}{*}{ Variables } & \multicolumn{4}{|c|}{ Replacement levels (\%) } & \multirow{2}{*}{$\mathrm{SEM}^{1}$} & \multicolumn{2}{|c|}{$P$ value } \\
\hline & 0 & 33 & 66 & 100 & & Linear & Quadratic \\
\hline \multicolumn{8}{|l|}{ Intake, kg/day } \\
\hline Dry pasture matter & 11.90 & 12.06 & 11.80 & 11.90 & 0.740 & 0.916 & 0.948 \\
\hline Total dry matter* & 15.29 & 15.45 & 15.19 & 15.28 & 0.716 & 0.916 & 0.949 \\
\hline Organic matter & 13.92 & 14.04 & 13.79 & 13.86 & 0.649 & 0.853 & 0.952 \\
\hline Crude protein & 2.87 & 2.89 & 2.84 & 2.86 & 0.135 & 0.852 & 0.972 \\
\hline Neutral detergent fiber & 7.71 & 7.80 & 7.65 & 7.70 & 0.415 & 0.895 & 0.950 \\
\hline Non-fiber carbohydrates & 2.34 & 2.41 & 2.45 & 2.48 & 0.154 & $0.030^{2}$ & 0.639 \\
\hline \multicolumn{8}{|l|}{ Digestibility, $(\%)$} \\
\hline Dry matter & 72.87 & 72.63 & 72.09 & 72.72 & 1.115 & 0.739 & 0.499 \\
\hline Organic matter & 74.27 & 73.92 & 73.26 & 73.91 & 1.068 & 0.5379 & 0.439 \\
\hline Crude protein & 76.65 & 77.08 & 76.14 & 76.43 & 1.293 & 0.640 & 0.930 \\
\hline Neutral detergent fiber & 60.01 & 59.99 & 58.78 & 62.06 & 1.630 & 0.287 & 0.132 \\
\hline
\end{tabular}


Supplementation of crossbred...

Table 3. Production and composition of milk, according to the substitution levels

\begin{tabular}{lccccccc}
\hline \multirow{2}{*}{ Variables } & \multicolumn{3}{c}{ Replacement levels $(\%)$} & \multirow{2}{*}{ SEM $^{1}$} & \multicolumn{2}{c}{$P$ value } \\
\cline { 2 - 4 } & 0 & 33 & 66 & 100 & & Linear & Quadratic \\
\hline Milk production, kg/day & 12.50 & 12.25 & 11.93 & 11.64 & 0.625 & $0.010^{2}$ & 0.891 \\
Milk production $^{3}, \mathrm{~kg} /$ day & 12.50 & 12.32 & 12.08 & 12.00 & 0.589 & 0.284 & 0.890 \\
Fat, g/day & 0.51 & 0.50 & 0.50 & 0.52 & 0.041 & 0.831 & 0.782 \\
Protein, g/day & 0.39 & 0.39 & 0.38 & 0.37 & 0.021 & 0.203 & 0.809 \\
Lactose, g/day & 0.61 & 0.60 & 0.59 & 0.59 & 0.030 & 0.226 & 0.766 \\
Total solids, kg/day & 1.64 & 1.53 & 1.59 & 1.60 & 0.109 & 0.859 & 0.481 \\
MUN $^{4}$,mg/dL & 18.35 & 18.06 & 17.52 & 17.36 & 2.558 & 0.169 & 0.899 \\
\hline
\end{tabular}

${ }^{1} \mathrm{SEM}=$ standard error of the mean $;{ }^{2} \hat{Y}=12.516-0.0087 \mathrm{x} ;{ }^{3}$ Milk production corrected for $4.0 \%$ of fat (kg/day); ${ }^{4} \mathrm{MUN}$ : milk urea nitrogen

Table 4. Feeding behavior and non-estearid acids, according to the substitution levels

\begin{tabular}{lccccccc}
\hline \multirow{2}{*}{ Variables } & \multicolumn{3}{c}{ Replacement levels $(\%)$} & \multirow{2}{*}{ SEM $^{1}$} & \multicolumn{2}{c}{$P$ value } \\
\cline { 2 - 4 } & 0 & 33 & 66 & 100 & & Linear & Quadratic \\
\hline $\mathrm{FT}^{2}, \mathrm{~min} /$ day & 430,0 & 453,3 & 421,7 & 461,7 & 15,08 & 0,610 & 0,762 \\
$\mathrm{RT}^{3}, \mathrm{~min} /$ day & 434,2 & 438,3 & 455,8 & 410,0 & 12,68 & 0,540 & 0,235 \\
$\mathrm{ST}^{4}, \mathrm{~min} /$ day & 575.8 & 548.3 & 562.5 & 568.3 & 13.10 & 0.961 & 0.661 \\
$\mathrm{TCT}^{5}, \mathrm{~min} /$ day & 864.2 & 891.7 & 877.5 & 871.7 & 12.77 & 0.961 & 0.661 \\
$\mathrm{PEDM}^{6}, \mathrm{~kg} \mathrm{MS} / \mathrm{h}$ & 2.29 & 2.18 & 2.27 & 2.16 & 0.10 & 0.686 & 0.990 \\
$\mathrm{FENDF}^{7}, \mathrm{~kg} \mathrm{FDN} / \mathrm{h}$ & 1.15 & 1.10 & 1.14 & 1.09 & 0.05 & 0.658 & 0.992 \\
$\mathrm{REDM}^{8}, \mathrm{~kg} \mathrm{DM} / \mathrm{h}$ & 2.17 & 2.16 & 2.08 & 2.37 & 0.07 & 0.364 & 0.256 \\
$\mathrm{RENDF}^{9}, \mathrm{~kg} \mathrm{NDF} / \mathrm{h}$ & 1.09 & 1.09 & 1.04 & 1.19 & 0.03 & 0.430 & 0.280 \\
$\mathrm{NEFA}^{10}, \mathrm{mmol} / \mathrm{L}$ & 0.15 & 0.14 & 0.14 & 0.14 & 0.003 & 0.577 & 0.335 \\
\hline
\end{tabular}

${ }^{1} \mathrm{SEM}=$ standard error of the mean; ${ }^{2} \mathrm{FT}=$ feeding time $;{ }^{3} \mathrm{RT}=$ rumination time $;{ }^{4} \mathrm{ST}=$ spare time $;{ }^{5} \mathrm{TCT}=$ total chewing time; ${ }^{6} \mathrm{PEDM}=$ power efficiency of dry matter; ${ }^{7} \mathrm{FENDF}$ = feeding efficiency Neutral detergent fiber; ${ }^{8} \mathrm{REDM}=$ rumination efficiency of dry matter; ${ }^{9} \mathrm{RENDF}=$ rumination efficiency of neutral detergent fiber; ${ }^{10} \mathrm{NEFA}=$ nonesterified fatty acids.

\section{DISCUSSION}

The CP content of the pasture were a consequence of pasture management associated with nitrogen fertilization and irrigation, and the lower range of grazing, 16 days. Fertilization, especially nitrogen, in addition to increasing the production of MS, increment the crude protein content of forage and, in some cases, reduce the fiber content and latter contribute to a better quality (Alencar $e t$ al., 2014).

The average intake of the DM (CDM) total was $15.30 \mathrm{~kg} / \mathrm{cow} /$ day, or $3.3 \%$ of the average animal BW. These values are consistent with those recommended by the NRC (2001), $13.7 \mathrm{~kg} / \mathrm{day}$ and $3.0 \%$ of the $\mathrm{BW}$, for a dairy cow weighing $457 \mathrm{~kg} \mathrm{BW}$, producing $12.5 \mathrm{~kg}$ of milk corrected to $4.1 \%$ of fat; which can be explained by the fact that foods with high nutritional value and high digestibility increment IDM, caused by the highest pass rate in the gastrointestinal tract. In addition, the stage of lactation that were the animals, the IDM is higher for them to recover their body reserves lost in early lactation, caused by DM intake limitation.

The increase in consumption of NFC occurred as a result of corn's NFC being higher than the soybean meal's NFC (Table 1), or by the decrease of the last nutrient content, as the bran soybean was removed from the feed.

The inclusion of corn and urea in concentrated replacing soybean meal kept the balance of rumen microflora and, consequently, high digestibility in the characteristics of the food provided, and the largest share of fiber quality through massive contributing for the maintenance of optimum conditions of the rumen, promoting salivation and maintenance of the proper $\mathrm{pH}$ for microbial activity (Guerra et al., 2018).

The high digestibility of forage is associated with a high concentration of soluble compounds in the leaves and narrower cell wall (Gurgel et al., 2020b). Another factor that may explain the high digestibility of NDF is the highest concentration 
of hemicellulose in NDF, a compound of better digestibility than cellulose (Gonzaga Neto et al., 2001). In this study, hemicellulose represented approximately $50 \%$ of the NDF (Table 1).

The urea nitrogen concentrations of milk (MUN) are above the reference ranges recommended by the literature, ranging from 10 to $15 \mathrm{mg} / \mathrm{dL}$ (Jonker et al., 1998; Johnson and Young, 2003). According to Jonker et al. (1998), the concentration of MUN may be considered one of the excess nitrogen excretion routes in the animal body and to indicate the excess of protein on the diet in form of degradable protein, which in this case took place with the participation of concentrated urea.

The feeding times observed in this study represent the values reported in the literature, for 4 to 12 hours per day in tropical cultivated pasture (Silva et al. 2010). The rumination time is determined by the quantity and quality of the diet provided, and it seems to be proportional to the cell wall of the bulky content (Van Soest, 1994). The main component of the diet of the animals was the pasture, which justifies the most time spent in rumination.

\section{CONCLUSION}

Total replacement of corn by soybean meal and urea to crossbreed cows in mid lactation, producing on average $12.5 \mathrm{~kg} / \mathrm{day}^{-1}$, held in Mombasa grass pastures irrigated and fertilized, it can be recommended, since dry matter intake, digestibility, corrected milk yield and milk components were not changed.

\section{ACKNOWLEDGMENTS}

The Coordination for the Improvement of Higher Education Personnel - Brazil (CAPES) Financing Code 001 and the National Council funded this research for Scientific and Technological Development (CNPq). Supported by the Federal University of Rio Grande do Norte and Federal University of Pernambuco.

\section{REFERENCES}

ALENCAR, C.A.B.; MARTINS, C.E.; OLIVEIRA, R.A. et al. Chemical composition and digestibility of the grasses cultivated under cut submitted the nitrogen fertilization and annual seasons. Biosci. J., v.30, p.8-15, 2014.

BÜRGER, P.J.; PEREIRA, J.C.; QUEIROZ, A.C. et al. Ingestive behavior in holstein calves fed diets with different concentrate levels. Rev. Bras. Zootec., v.29, 236-242, 2000.

DETMANN, E.; SOUZA, M.D.; VALADARES FILHO, S.C. et al. Métodos para análise de alimentos - INCT - Ciência Animal. Visconde do Rio Branco: Suprema, 2012.

DIFANTE, G.S.; EUCLIDES, V.P.B.; NASCIMENTO JÚNIOR, D. et al. Performance and feed conversion of beef cattle steers on Tanzania guineagrass under two grazing intensities and rotational stocking. Rev. Bras. Zootec., v.39, p.33-41, 2010.

EMERENCIANO NETO, J.V.; DIFANTE, G.S.; MEDEIROS, H.R. et al. Cultivated pastures affect nutrient intake and feeding behavior of sheep. Trop. J. Anim. Sci., v.43, p.117-124, 2020.

EUCLIDES, V.P.B.; CARPEJANI, G.C.; MONTAGNER, D.B. et al. Maintaining postgrazing sward height of Panicum maximum (cv. Mombaça) at $50 \mathrm{~cm}$ led to higher animal performance compared with post- grazing height of $30 \mathrm{~cm}$. Grass Forage Sci., v.73, p.174-182, 2018.

GONÇALVES, G.S.; PEDREIRA, M.S.; AZEVEDO, J.A.G. et al. Replacement of soybean meal by conventional and coated urea in dairy cows: intake, digestibility, production and composition of milk. Acta Sci. Anim. Sci., v.36, p.71-78, 2014.

GONZAGA NETO, S.; BATISTA, A.M.V.; CARVALHO, F.F.R. et al. Bromatological composition, intake and in vivo digestibility of the diets with different levels of "catingueira" hay (Caesalpinea bracteosa), fed to Morada Nova sheep. Rev. Bras. Zootec., v.30, p.553-562, 2001. 
GUERRA, M.G.; VERAS, A.S.C.; SANTOS, V.L.F. et al. Protein metabolic profile of dairy cows fed corn and urea pasture. Arq. Bras. Med. Vet. Zootec., v.70, p.1266-1274, 2018.

GURGEL, A.L.C.; DIFANTE, G.S.; ARAUJO, A.R. et al. Carbon and nitrogen stocks and soil quality in an area cultivated with Guinea grass under the residual effect of nitrogen doses. Sustainability, v.12, p.9381, 2020a.

GURGEL, A.L.C.; DIFANTE, G.S.; EMERENCIANO NETO, J.V. et al. Supplementation of lamb ewes with different protein sources in deferred marandu palisadegrass (Brachiaria brizantha cv. marandu) pasture. Arq. Bras. Med. Vet. Zootec., v.72, p.1901-1910, 2020b.

ÍTAVO, L.C.V.; ÍTAVO C.C.B.F.; DIAS, A.M. et al. Combinations of non-protein nitrogen sources in supplements for Nellore steers grazing. Rev. Bras. Saúde Prod. Anim., v.17, p.448-460, 2016.

JOHNSON, M.M.; PETERS, J.P. Technical note: an improved method to quantify nonesterified fatty acids in bovine plasma. J. Anim. Sci., v.71, p.753-756, 1993.

JOHNSON, R.G.; YOUNG, A.J. The association between milk urea nitrogen and DHI production variables in Western comercial dairy herds. $J$. Dairy Sci., v.86, p.3008-3015, 2003.

JONKER, J.S.; KOHN, R.A.; ERDMAN, R.A. Using milk urea nitrogen to predict nitrogen excretion and utilization efficiency in lactating dairy cows. J. Dairy Sci., v.81, p.2681-2692, 1998.
MORAES, G.J.; ÍTAVO, L.C.V.; ÍTAVO, C.C.B.F. et al. Extruded urea could reduce true protein source in beef cattle diets. J. Anim. Physiol. Anim. Nutr., v.103, p.1283-1294, 2019.

NAVES, J.R.; JESUS, E.F.; BARREIRO, J.R. et al. Partial replacement of soybean meal by different nitrogen Sources in diets based on sugarcane as forage to feeding of Dairy cows. Vet. Zootec., v.22, p.101-113, 2015.

NUTRIENT requirements of dairy cattle. 7.ed. rev. Washington: National Academy Press, 2001.

PONTES, V.P.; ALCALDE, C.R.; PILI, F.M.S. et al. Nutritive value of Saanen goat diets with dried distillers grains with solubles as a replacement for soybean meal. Rev. Bras. Zootec., v.49, p.e20190279, 2020.

SILVA, R.R.; PRADO, I.N.; SILVA, F.F. et al. Diurnal ingestive behavior of Nellore steers receiving increasing levels of supplement in brachiaria pasture. Rev. Bras. Zootec., v.39, p.2073-2080, 2010.

TEIXEIRA, P.C.; DONAGEMMA, G.K.; FONTANA, A.; TEIXEIRA, W.G. (Eds.). Manual de métodos de análise de solo. 3.ed. rev. ampl. Brasília, DF: Embrapa, 2018, 573p.

VALENTE, T.N.P.; DETMANN, E.; VALADARES FILHO, S.C. et al. In situ estimation of indigestible compounds contents in cattle feed and feces using bags made from different textiles. Rev. Bras. Zootec., v.40, p.666675, 2011.

VAN SOEST, P.J. Nutritional ecology of the ruminant. 2.ed. Ithaca: Cornell University, 1994. 